\title{
Det brenner et blått lys for profesjonsetikken
}

Fremover blir det viktig å være bevisst på etikken i sykepleieutøvelsen. Vi må alltid stå opp for verdiene og standardene som er til pasientens beste.

\section{Elisabeth Sveen Kjølsrud}

Leder

Rådet for sykepleieetikk

Profesjonsetikk

Sykepleieutøvelse

Verdier

Sykepleien 2019107 (79311) (e-79311)

DOI: 10.4220/Sykepleiens.2019.79311

Sykepleiere høster stor tillit i befolkningen. De har god faglig kunnskap der profesjonsetikken står sentralt. Imidlertid ser vi stadig flere utfordringer og dilemmaer som sykepleiere må forholde seg til i det daglige arbeidet.

Denne etikkartikkelen handler om et press på de profesjonsetiske verdiene som konstant blir sterkere. Belastningen mellom sykepleiernes lojalitet til arbeidsgiveren versus pasienten og deres profesjonsetiske verdier er vedvarende.

I rapporten til landsmøtet i november 2019 skriver Rådet for sykepleieetikk at profesjonsetikken i stadig større grad står i skvis mellom de organisatoriske verdiene. 


\section{Tydelig, modig og stolt}

Mottoet til sykepleiere er «tydelig, modig og stolt».

Rammene rundt sykepleieutøvelsen kan gå på

stoltheten $1 \varnothing$ s. Stolthet henger sammen med en

identitetsfølelse og tilhørighet med arbeidsplassen du

jobber på.

Stolthet har også en sammenheng med eget arbeid og hvordan hver enkelt opplever å etterleve målet man har i jobben, og ikke minst hva fellesskapet oppnår sammen. Slike verdier er under press.

\section{«De som bestemmer over pengesekken, sitter langt borte fra dem som utøver tjenestene.»}

Effektivitet er i høysetet, og sykepleierne arbeider under tidspress. Mange forstår ikke den organisatoriske ideologien som råder. Den oppleves ikke naturlig og virker fremmedgjørende. De som bestemmer over pengesekken, sitter langt borte fra dem som ut $\varnothing$ ver tjenestene.

Det er krevende å varsle om uforsvarlige hendelser, og fører ikke alltid frem. To varslere fra min egen forskning forteller om at de fikk klage fra overordnede om å holde en lavere profil, og de fikk sterk kritikk. En annen sier fortvilet: «Vi kan ikke bare varsle og varsle, da får vi intet gjort.» Varslersakene er mange.

\section{Samfunnet er utålmodig}

For mange år tilbake leste jeg Richard Sennetts klassiker Det fleksible mennesket. Personlige konsekvenser av å arbeide $i$ den nye kapitalismen (1). Boken handler i grove trekk om dype spørsmål om vår karakter og de personlige egenskapene vi verdsetter ved oss selv, som vi ønsker at også andre skal verdsette. Hva har varig verdi i oss selv, når samfunnet er så utålmodig og kun fokuserer på det umiddelbare? spør Sennett. 
I boken The Craftsman (2) peker igjen Sennett på verdiene og betydningen av en forankring av disse. Han skriver følgende: «Most of us have work to do. But is work just a means to an end? In trying to make a living have we lost touch with the idea of making things well.» (2, s. 8) Sennetts ord treffer sykepleiernes hverdag.

\section{Robuste sykepleiere}

I Danmark, da den danske sykepleierutdannelsen ble revidert i 2015 og 2016, etterlyste representanter for arbeidsgiverne at det ble utdannet robuste sykepleiere. Det var en oppfattelse at en del nyutdannede sykepleiere ikke tålte presset; det vil si at de ikke kunne stå i en presset arbeidsdag med svært høy pasientgjennomstrømning og en stor arbeidsbyrde.

Også i danske stillingsutlysninger blir det etterlyst robuste sykepleiere. Underforstått i disse utlysningene ligger et behov for sykepleiere som er sterke og motstandsdyktige overfor store belastninger.

\section{«Sykepleiere er ikke bare rasjonelle aktører som tåler alt.»}

I Norge annonseres det etter fleksible sykepleiere, skriver Steenberg, Quinteros og Kjølsrud i boken Profesjonsetikk. Velferdsarbeid for og med mennesker (3).

Verdier i samfunnet basert på effektivitet og bedrifts $\varnothing$ konomiske modeller er tilpasset et rasjonelt tankesett. Sykepleiere er ikke bare rasjonelle aktører som tåler alt. Sykepleiens grunnlag er respekten for det enkelte menneskets liv og iboende verdighet.

Sykepleie skal bygge på barmhjertighet, omsorg og respekt for menneskerettighetene. Det grunnleggende er at etikken oppstår i møtet med et annet menneske ansikt til ansikt. Her er sansningen sentral. Sansningen kan fort utebli i travelheten. 


\section{Moralsk stress}

Jeg er bekymret over at sykepleiere og andre helsearbeidere må gå på akkord med sin egen samvittighet. Vi har nå i mange år fått tydelig forskning på at sykepleiere der ute opplever mer og mer moralsk stress. Smertegrensen er nådd, og det er på tide at dette blir tatt på alvor.

Lite innflytelse på arbeidshverdagen blir også stadig rapportert. Vi blir mer og mer umyndiggjort, skriver den danske sosiologen Rasmus Willig i boken Umyndiggjørelse (4). Presset gjelder også andre fagprofesjoner.

De siste dagene har det stått omtalt at legenes standarder står under press fra styresmakter. Et sentralt moment her er å bruke mindre tid på pasienten.

Sykepleiere må stå fast ved de profesjonsetiske standardene sine i fremtiden. Vi må ikke glemme vår historie, både på godt og vondt. Pliktetikken, og hva vi blir bedt om å gjøre, må alltid gjennom en faglig refleksjon.

\section{«Heldigvis lever vi ikke i et autoritært regime $i$ Norge i dag, og sykepleiernes stemme er synlig og hørbar.»}

Gruppepress kan endre våre tanker og holdninger, eksempelvis bør Stanley Milgrams

lydighetseksperimenter ikke gå i glemmeboken.

Hensikten med den studien var å se hvor langt fors $\varnothing$ kspersonene var villige til å gå før de nektet å fortsette. Situasjonen var stressende, men viste at mennesker er villige til å gå langt etter ordre fra autoritetspersoner.

Det mest oppsiktsvekkende var at 65 prosent av deltakerne var villige til å gi en dødelig dose, noe som selvfølgelig var oppsiktsvekkende og skapte store overskrifter. Eksperimentet fant sted på 6o-tallet. 
Er det nødvendig å trekke frem et så grotesk eksempel? spør du sikkert. Hvis vi ser på historien, ser vi også at sykepleiere har underordnet seg autoritære regimer. Heldigvis lever vi ikke i et autoritært regime i Norge i dag, og sykepleiernes stemme er synlig og hørbar.

Likevel tror jeg det er nødvendig at vi forstår at det er kamp om viktige verdier i samfunnet vårt. Profesjonsetikken i landet vårt og i vesten er under press.

Medlemmer i Rådet for sykepleieetikk har i denne perioden (2015-2019) lansert begrepet «etisk risikosone». Det er et begrep som er viktig å ha med seg ute i praksis. Hva står på spill i situasjonene en sykepleier kommer opp i?

\section{Til pasientens beste}

Sykepleiere har altså mottoet «tydelig, modig og stolt». Sykepleiere høster stor tillit ute i befolkningen, og det er et viktig motto som må hegnes om. Stoltheten synes å være under press - det er ikke alltid like enkelt å være stolt over eget arbeid og forstå organisasjonens verdier og mål når faglige og profesjonsetiske vurderinger har trenge kår.

Fremover blir det viktig aldri å lene seg tilbake, men være bevisst på etikken i sykepleieutøvelsen. Som profesjonelle må vi alltid stå opp for verdiene og standardene som er til pasientens beste.

Denne tematikken er blitt beskrevet mange ganger. Nå er det på tide at noe skjer. Det brenner et blått lys for profesjonsetikken, og vi må ikke sove.

Politikere og ledere må ta ansvar for at ressurser og organisering danner en human ramme omkring det faglige, profesjonelle arbeidet i helsevesenet.

Helsepolitikken skal baseres på humane verdier, og sykepleiernes og pasientenes erfaringer må anerkjennes som en viktig del av beslutningsgrunnlaget. 


\section{Referanser}

1. Sennett R. Det fleksible mennesket. Personlige konsekvenser av å arbeide i den nye kapitalismen. Oslo: Fagbokforlaget Vigmostad \& Bjørke; 2001.

2. Sennett R. The Craftsman. London: Penguin Books; 2008.

3. Stenberg D, Quinteros R, Kjølsrud ES. Etikk og robusthet. I: Hjort K, Kristiansen A, Barkholt NC, red. Profesjonsetikk. Velferdsarbeid for og med mennesker. Oslo: Gyldendal; 2018. s. 52.

4. Willig R. Umyndiggørelse. Århus: Hans Reitzels Forlag; 2009. 